\title{
IMPACT OF HUMAN RESOURCES' "ENERGY” ON THE DEVELOPMENT OF BUSINESS ENTITIES
}

\author{
Anna Pereverzieva ${ }^{1}$, Volodymyr Volkov ${ }^{2}$ \\ Zaporizhzhia National University, Ukraine
}

\begin{abstract}
The purpose of the paper is to define the impact of human resources' "energy" on the development of business entities based on the physical concept of kinetic and potential energy. Methodology. Mathematical dependencies for determining kinetic and potential energy are applied in the study. The first step to identify the impact of human resources "energy" on communities' performance and development is to sort them into four groups based on analytical tools. The next step in the process of community's energy influence on its performance and development is the application of discriminant analysis. Discriminant analysis is used to group and define the nature of the correlation between the number of human resources and business entity's development rate. Mathematical transformations of kinetic and potential energy formulas allowed defining the characteristics of correlation between the number of group members and the level of interactions: direct or inverse relationship. Singling out and grouping allowed to establish the fact of the existence of the correlation between the rate of development and the number of human resources, as well as the nature of the relationship. Four groups of communities were singled out on the basis of analytical tools and discriminant analysis application: with high kinetic energy rate and considerable number of community members; with low kinetic energy rate and inconsiderable number of community members; with low kinetic energy rate and considerable number of community; with high kinetic energy rate and inconsiderable number of community members. We proposed the approach to assess the potential energy rate. It can be used to quantify the "energy" of interactions, which is characterized by qualitative indicators. The data used in the study is the information of statistical databases illustrating business entities' functioning. Results of the survey showed a direct correlation between the kinetic and potential energy of human resources, that is, between business entity's development and the level of its components' interactions. Practical implications. Identification and quantitative assessment of business entities' human resources "energy" require working out an effective mechanism for managing human resources' "energy" to preserve and develop it in the future. This causes chain reaction, contribute to the achievement of high efficiency and effectiveness of their activities in the future. Value/originality. While human resources are a concept that reflects the key wealth of any society, the ability to manage the collective mental energy embodied in human resources, is scarcely studied. It is a gap we strive to fill in this manuscript.
\end{abstract}

Key words: energy, human resources, impact, kinetic energy, potential energy, grouping.

JEL Classification: D310, J210, 0150

\section{Introduction}

Functioning and development of business entities cannot be imagined without human resources. Their significance is growing dynamically with the development of the economy and the complexity of interconnections between its components. People are the only "element" that can create value, whilst equipment, raw materials, and materials are only inert potentials, which by their nature do not create anything and cannot create until a person uses this potential, forcing it to work (Fitz-enz, 2006). Each person has own abilities which determine potential opportunities used in everyday life in general and when working, in particular. Although, a person can have a significant amount of knowledge and abilities, but does not put them into expected effect. After all, the maximum effect can only be achieved through the interactions of human resources. As a result, a certain amount of "energy" is being accumulated. This promotes the formation of a united team, based not only on the distribution of roles and places but on mutual support and assistance in

Corresponding author:

${ }^{1}$ Department of International Economics, Natural Resources and Economic Theory, Zaporizhzhia National University.

E-mail: pereverzeva@ukr.net

${ }^{2}$ Department of Entrepreneurship, Management of Organizations and Logistics, Zaporizhzhia National University.

E-mail:volkovvp49@gmail.com 
achieving common goals. People do not differ so much in the amount of knowledge, but in their great potential to benefit from the knowledge of other people (Hayek, 2006). To our knowledge, the study of human resources' "energy" impact on the development of business entities is highly demanded. That is what will be conceptualized in this manuscript.

The motivation for our work is the desire of business entities to improve the results of their activities by identifying latent opportunities, which, at the same time, do not require significant material costs. Latent opportunity is the "energy" of human resources' interactions in a certain team, which brings additional benefits because of skilful management. Classification of human resources' interactions and their impact assessment allow us to identify the set of tools and management methods that will differ and depend on the characteristics of a business entity.

The objective of our study is to determine the impact of human resources' "energy" on the development of business entities, which allows us to form a "portfolio" of tools and methods of human resource management. This article focuses on the definition of two types of human resources' "energy": kinetic, associated with the rate of development and potential, which determines the level of human resources' interactions. Besides, we determine the existence of interactions between these types of human resources' "energy".

Nowadays the processes of decentralization accompanied by the formation of communities take place in Ukraine; the example of united territorial communities' activities as business entities illustrates the influence of human resources' "energy" on the development. The communities are considered a good example. They are formed both in accordance with certain objective criteria, determined at the legislative level, and voluntary. In our opinion, it is a difficult task for communities to combine and accumulate the "energy" of human resources as a whole, since territorial units, which have joined the community, used to function separately.

Physical concepts of these properties and their quantitative calculations are used to determine the kinetic and potential "energy" of human resources in the study. Analytical dependencies, as well as discriminant analysis for the division of business entities into groups based on criterion features, like the detection of the business entities' kinetic energy dependence rate (development rate) and the number of human resources, are used as analytical tools. Based on the formulas of kinetic and potential energy analysis, as well as their mutual transformations, we determined the impact of human resources' interactions "energy" on the rate of business entities' development.

As a result of our study, the impact of human resources "energy" on the development of a community as a business entity was proved. Based on the study of 23 communities' operation, direct dependency between the number of community members and development rate $(56 \%)$ was identified. 8 communities (35\% of the total number of studied communities) had high kinetic energy rate and significant number of community members; 6 communities ( $21 \%$ of the total number of studied communities) had a low kinetic energy rate and inconsiderable number of community members.

The results of the study show that in $44 \%$ of cases the development rate depends to a small extent on the number of people. This is proved by the fact of another type of energy existence, which "guides" development. 7 communities (30\% of the total number of studied communities) had low kinetic energy rate and a significant number of community members; 2 communities ( $4 \%$ of the total number of studied communities) had high kinetic energy rate and an inconsiderable number of community members. This is the potential energy, i.e. the energy of human resources' interactions.

The remainder of the article is organized as follows. Our literature review encompasses separate sections to define the concepts of "energy", "human resources". We describe then the data and methods in detail prior to sharing our results. A discussion of those results, limitations, and future research avenues conclude the article.

\section{The concept of "human resources"}

Current reality reveals that most business entities are seeking to accumulate wealth in the form of financial capital. Excessive focus on maintaining only financial capital, ignoring the importance of human and intellectual capital, can negatively affect the performance of a business entity (Hughes-Jr., James, 2007). Schulz, T.W. and Becker, G.S. in their studies regarded people and their skills as capital (Becker, 2003, Schulz, 1960). The scholars analysed human resources from the investment point of view. They distinguished two types of investments in people. General investments are investments in the development of knowledge and skills that increase the productivity of a worker who receives them, regardless of an organization in which a person works (training to operate a personal computer). Special investments are funding for knowledge and skills that increase the future productivity of its recipient only in an organization where a person is taught (awareness of structure and internal routine of an enterprise).

In our opinion, now the success of business entities depends on the ability to manage the collective mental energy embodied in human resources, which combines the roles of ideas generator, spiritual personality, producer, and consumer.

There are different approaches to the definition of "human resources" concept in scientific literature.

In a general sense, human resources are a concept that reflects the key wealth of any society whose prosperity is possible due to the created conditions for reproduction, use, and development of these resources, 
taking into account the interests of each person (Great Encyclopaedic Dictionary).

The microeconomic aspect of human resources was considered by E. Flamholtz, who is the author of human resources' accounting concept, and of three concepts of human resources assessing, namely by original or historical costs; replacement costs; opportunity costs. According to his studies, human resources are an asset on the basis of certain criteria, namely potential benefit; ownership or control rights of a business entity; monetary value (Flamholtz, 1999).

A foreign researcher J. Fitz-enz argued the importance of human resources. The scholar noted that people are the only essential feature, which creates value, whereas equipment, raw materials, and energy are just inert potentials, which in their nature do not create anything and cannot create until people use this potential, forcing it to work (Fitz-enz, 2006).

It is worth agreeing with the World Bank researchers who consider human resources as the total value of labour resources and human capital (Adapted version of the book "More than economic growth").

Essential characteristics of human resources are in the definition of L. Semiv. The scholar gives the following definition of human resources: a set of human qualities (socio-demographic, educational and professional, motivational, mental, intellectual, spiritual and informational, innovative, creative, cultural, ethnosocial, socialization, etc.), which determine the ability of a person to work, consume material and spiritual goods, self-development, generate innovations, multiply knowledge in all areas of life (Semiv, 2004).

Considering the concept of human resources in terms of the innovation economy, they are defined as a category, which characterizes qualitative, content components of personnel or the entire staff of an enterprise, labour force or labour resources, industry, territory, region, country as a whole. Along with the traditional features essential to staff, personnel, labour force, labour resources, the category "human resources" combines creative ability, determines the potential for the full development of workers, common culture and moral reliability, a certain effect of cooperation and self-organization, and foremost, collective forms of work organization and decisionmaking, "quality teams", "team's spirit", as well as improvement of labour relations, self-motivation, ingenuity (Dokashenko, Bobrova, 2011).

As international experts point out, it is important to realize when examining human resources that if people involved in the production process do not perceive their work as important and necessary activity, it is unlikely to achieve significant results. Sharing common objective spurs the interest of participants (Human resources in American management).

According to G.V. Shchokin, "human resources refer to quantitative, content component of personnel or the entire staff of an organization, the labour force or labour resources of an industry, region, country as a whole. Along with traditional features inherent in the elements of the defined set (staff, personnel, labour force, labour resources), the concept of "human resources" integrates creative ability and prospect to reach workers' full potential, common culture, moral, and psychological qualities, a certain impact of cooperation and selforganization (corporate identity, "team spirit", collective forms of work organization, etc.) (Shchokin, 2006).

The literature review provides the theoretical definition of the "human resources" category, which indicates a significant influence of human abilities and qualities on a business entity's performance by means of cooperation, self-organization, and team spirit. The result is an accumulation of collective energy of people and its concentration within a certain environment.

\section{3. "Energy" of human resources}

The word "energy" from Greek means "action". Energetic people act energetic, carrying out a number of diverse activities. In everyday life, we can evaluate human energy mainly by the consequences of the activity. However, it should be noted that the energy of one person, even if it was maximized, would not give the same result as the use of the sum of people association's energy potentials. As people association one can consider enterprise's staff as a whole or its separate structural subdivision, as well as a community. There is the difference in enterprise's staff formation on the basis of skills level, functional responsibilities, whereas communities are voluntary associations of people according to certain features. In this regard, human resources of enterprises, communities form their "energy", which accumulation should be the impetus for their further development.

K. Jonassen (Jonassen, 1959) and J. Hillery (Hillery, 1955) emphasize the need for interactions within a community for its effective functioning. They define a territorial community as an association of people within a territory, with the division of labour into specialized and interrelated functions, with a common culture and social system, which organizes its activities, has members who are aware of their integrity, belonging to a community and act as one orderly. J. Hillery (Hillery, 1955) concluded that, though there are differences, most of them have the following key features: social interactions, territory, and general coherency.

We propose the following hypotheses for testing:

H1: Human resources energy impacts business entity's development;

H2: There is a direct correlation between kinetic energy rate (development rate) of a business entity and amount of human resources

H3: Potential energy (coherence energy) impacts development rate of a business entity 


\section{Survey methodology}

We considered united territorial communities of Zaporizhzhia region as business entities. The study of 23 united territorial communities was conducted by 2016 , starting from the year of their foundation. To determine the impact of human resources "energy" on the development of business entities, which is the objective of the study, communities were divided initially into four groups on the basis of analytical tools and then discriminatory analysis, which confirmed the direct correlation between the community's development rate and the amount of human resources. The conversion of kinetic and potential energy formulas showed the impact of community's human resources interactions' energy on its development rate.

In the research when studying community's human resources "energy" it was used Physics' energy classification - kinetic and potential. The kinetic energy $\left(W_{k}\right)$ means the energy of the mechanical motion of a particular system. The kinetic energy of a community as a system is the energy of this system 's motion. The efficiency of interactions between human resources influences the development of the system in the future.
To calculate the kinetic energy of a community, we use the formula:

$$
W_{\kappa}=\frac{m V^{2}}{2},
$$

where:

$W_{k}$ - community's kinetic energy;

$\mathrm{m}$ - the number of community members, persons;

$\mathrm{V}$ - community's development rate.

To define a community's development rate we use the formula:

$$
V=\frac{S}{t}
$$

where:

$S$ - the level of community's self-sufficiency;

$t$ - a period of community's performance, starting from its foundation by the end of the analysed period, years;

To define the level of self-sufficiency we use the formula:

$$
S=\frac{R_{o w n}}{C}
$$

where:

Table 1

\begin{tabular}{|c|c|c|c|c|c|}
\hline \multirow[t]{2}{*}{ Community } & $\begin{array}{c}\text { Number of } \\
\text { community } \\
\text { members, persons }\end{array}$ & $\begin{array}{l}\text { Level of self- } \\
\text { sufficiency }\end{array}$ & $\begin{array}{c}\text { Period of } \\
\text { community's } \\
\text { performance, years }\end{array}$ & $\begin{array}{c}\text { Community's } \\
\text { development } \\
\text { rate }\end{array}$ & Kinetic energy \\
\hline & $\mathrm{m}$ & $S$ & $\mathrm{t}$ & $\mathrm{V}$ & $\mathrm{W}_{\mathrm{k}}$ \\
\hline 1 & 2 & 4 & 5 & 6 & 7 \\
\hline 1 Berestivska rural community & 4751 & 1,0215 & 2,0 & 0,51 & 619,69 \\
\hline 2 Bilenkivska rural community & 9226 & 0,3722 & 1,0 & 0,37 & 639,05 \\
\hline 3 Velykobilozerska rural community & 7936 & 0,4003 & 0,5 & 0,80 & 2543,33 \\
\hline 4 Veselivska settlement community & 10794 & 0,7912 & 2,0 & 0,40 & 844,63 \\
\hline 5 Vodyanska rural community & 11309 & 0,5392 & 0,5 & 1,08 & 6575,88 \\
\hline 6 Voskresenska rural community & 5695 & 0,3983 & 2,0 & 0,20 & 112,93 \\
\hline 7 Girsivska rural community & 2587 & 0,5271 & 1,0 & 0,53 & 359,38 \\
\hline 8 Gulyajpilska urban community & 16900 & 0,6828 & 0,5 & 1,37 & 15758,10 \\
\hline 9 Dolynska rural community & 5800 & 0,6848 & 1,0 & 0,68 & 1359,96 \\
\hline $\begin{array}{l}10 \text { Kamjansko-Dniprovska urban } \\
\text { community }\end{array}$ & 22273 & 0,5373 & 0,5 & 1,07 & 12860,04 \\
\hline 11 Komysh-Zoryanska settlement & 6466 & 0,3421 & 2,0 & 0,17 & 94,59 \\
\hline 12 Komyshuvaska settlement community & 13157 & 0,1928 & 1,0 & 0,19 & 244,53 \\
\hline 13 Malotokmachanska rural community & 3166 & 1,0570 & 1,0 & 1,06 & 1768,61 \\
\hline 14 Orihivska urban community & 19648 & 0,9722 & 0,5 & 1,94 & 37141,51 \\
\hline 15 Osypenkivska rural community & 7830 & 0,4976 & 1,0 & 0,50 & 969,38 \\
\hline 16 Ostrykivska rural community & 2930 & 1,1443 & 1,0 & 1,14 & 1918,30 \\
\hline 17 Pavlivska rural community & 3800 & 0,6094 & 0,5 & 1,22 & 2822,40 \\
\hline 18 Preobrazhenska rural community & 5902 & 1,1236 & 2,0 & 0,56 & 931,39 \\
\hline 19 Prymorska urban community & 14698 & 0,5283 & 1,0 & 0,53 & 2051,11 \\
\hline 20 Smyrnovska rural & 3846 & 0,1919 & 2,0 & 0,10 & 17,70 \\
\hline 21 Tavrijska rural community & 4494 & 0,3095 & 1,0 & 0,31 & 215,24 \\
\hline 22 Chernigivska settlement community & 17100 & 0,5231 & 0,5 & 1,05 & 9358,27 \\
\hline 23 Shyrokivska rural community & 11201 & 0,5469 & 0,5 & 1,09 & 6700,43 \\
\hline
\end{tabular}

Indicators of human resources' energy definition illustrated by the example of Zaporizhzhia region's communities

Source: own calculations based on data from the [Investment potential of Zaporizhzhia region united territorial communities. Ministry of regional development, construction, housing and communal services of Ukraine. Communities] 
$S$ - the level of community's self-sufficiency;

$R_{\text {own }}$ - the volume of community's own revenues, mln.hrn;

C - the volume of community's expenditures, mln.hrn.

The results of calculations are shown in Table 1.

Table 1 data show that communities with a substantial number of human resources have a considerable rate of kinetic energy.

Thus, according to the presented calculations, it can be concluded that the development - the motion forward - of a certain business entity (enterprise, community) depends on the level of human resources endowment. The kinetic energy of human resources is a quantitative indicator, associated with extensive development - the more human resources are used, the higher the level of community's self-sufficiency is.

Table 2

Indicators to determine the correlation between the number of community members $(\mathrm{m})$ and its kinetic energy rate by grouping

\begin{tabular}{|c|c|c|}
\hline Community & $\begin{array}{c}\text { Kinetic } \\
\text { energy rate }\end{array}$ & $\begin{array}{c}\text { Number of } \\
\text { community } \\
\text { members, } \\
\text { persons }\end{array}$ \\
\hline & $\mathrm{X}_{1}$ & $\mathrm{X}_{2}$ \\
\hline 1 Berestivska rural community & 37141,51 & 19648 \\
\hline 2 Bilenkivska rural community & 12860,04 & 22273 \\
\hline 3 Velykobilozerska rural community & 2543,33 & 7936 \\
\hline 4 Veselivska settlement community & 15758,10 & 16900 \\
\hline 5 Vodyanska rural community & 244,53 & 13157 \\
\hline 6 Voskresenska rural community & 969,38 & 7830 \\
\hline 7 Girsivska rural community & 844,63 & 10794 \\
\hline 8 Gulyajpilska urban community & 17,70 & 3846 \\
\hline 9 Dolynska rural community & 112,93 & 5695 \\
\hline $\begin{array}{l}10 \text { Kamjansko-Dniprovska urban } \\
\text { community }\end{array}$ & 215,24 & 4494 \\
\hline $\begin{array}{l}11 \text { Komysh-Zoryanska settlement } \\
\text { community }\end{array}$ & 1359,96 & 5800 \\
\hline $\begin{array}{l}12 \text { Komyshuvaska settlement } \\
\text { community }\end{array}$ & 6575,88 & 11309 \\
\hline \multicolumn{3}{|l|}{$\begin{array}{l}13 \text { Malotokmachanska rural } \\
\text { community }\end{array}$} \\
\hline 639,05 & 9226 & \\
\hline \multicolumn{3}{|l|}{14 Orihivska urban community } \\
\hline 1768,61 & 3166 & \\
\hline 15 Osypenkivska rural community & 9358,27 & 17100 \\
\hline 16 Ostrykivska rural community & 359,38 & 2587 \\
\hline 17 Pavlivska rural community & 2051,11 & 14698 \\
\hline 18 Preobrazhenska rural community & 1918,30 & 2930 \\
\hline 19 Prymorska urban community & 931,39 & 5902 \\
\hline 20 Smyrnovska rural community & 619,69 & 4751 \\
\hline 21 Tavrijska rural community & 2822,40 & 3800 \\
\hline $\begin{array}{l}22 \text { Chernigivska settlement } \\
\text { community }\end{array}$ & 6700,43 & 11201 \\
\hline 23 Shyrokivska rural community & 94,59 & 6466 \\
\hline
\end{tabular}

Source: Compiled by the author
To determine the correlation between the number of community members $(m)$ and its kinetic energy rate, we apply analytical tools. We use the data in Table 2 as statistics.

To group communities according to the number of community members and kinetic energy rate we use mathematical relations, which allow distinguishing classification characteristics of communities' division based on the kinetic energy rate analysis and the number of community members (Table 3 ).

Table 3

Community's grouping criteria

\begin{tabular}{|l|c|}
\hline \multicolumn{1}{|c|}{ Rate } & Criterial value \\
\hline High rate & $X_{1}>\overline{X_{1}}, X_{2}>\overline{X_{2}}$ \\
\hline Low rate & $X_{1}<\overline{X_{1}}, X_{2}<\overline{X_{2}}$ \\
\hline
\end{tabular}

Note: $X_{1}, X_{2}$ - kinetic energy rate and number of community members, accordingly;

$\bar{X}_{1}, \bar{X}_{2}$ - average values of united territorial communities, accordingly.

The average values of indicators are calculated as "geometric mean", which allows harmonizing of the high and low values of the indicators:

$$
\sqrt[N]{\prod_{i=1}^{N} X_{i}}
$$

where:

$X_{i}$ - the value of i-index;

$N$ - a number of united territorial communities by the group.

The average value by the kinetic energy rate $\bar{X}_{1}=1266$ mln.hrn, by a number of community members $\overline{X_{2}}=7599$ persons.

For comparison, we construct a matrix for the classification of united territorial communities based on correlations "the kinetic energy rate - the number of community members" (Table 4).

It should be summarized according to the abovementioned that $56 \%$ of communities are characterized by the direct correlation between the kinetic energy rate and the number of community members.

For the further communities grouping, we use discriminatory analysis, which makes it possible to classify objects by a certain set of characteristics. In addition, this method allows identifying the differences between groups and provides the opportunity to classify new objects on the principle of maximum similarity.

Consider two groups of united territorial communities characterized by the direct correlation between the kinetic energy rate and the number of community members (Table 5).

According to the calculations, a vector of the discriminant function parameters was obtained: 
Table 4

The matrix of the united territorial communities' classification based on correlations "the kinetic energy rate the number of community members"

\begin{tabular}{|c|c|c|c|}
\hline \multirow{4}{*}{ 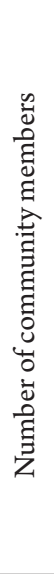 } & \multicolumn{3}{|c|}{ Kinetic energy } \\
\hline & Rate & High rate & Low rate \\
\hline & 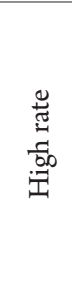 & $\begin{array}{l}\text { Berestivska rural community } \\
\text { Bilenkivska rural community } \\
\text { Velykobilozerska rural community } \\
\text { Veselivska settlement community } \\
\text { Komyshuvaska settlement community } \\
\text { Osypenkivska rural community } \\
\text { Pavlivska rural community } \\
\text { Chernigivska settlement community }\end{array}$ & $\begin{array}{l}\text { Vodyanska rural community } \\
\text { Girsivska rural community } \\
\text { Gulyajpilska urban community } \\
\text { Dolynska rural community } \\
\text { Kamjansko-Dniprovska urban community } \\
\text { Komysh-Zoryanska settlement community } \\
\text { Malotokmachanska rural community }\end{array}$ \\
\hline & 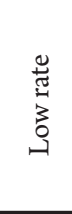 & $\begin{array}{l}\text { Orihivska urban community } \\
\text { Preobrazhenska rural community }\end{array}$ & $\begin{array}{l}\text { Voskresenska rural community } \\
\text { Ostrykivska rural community } \\
\text { Prymorska urban community } \\
\text { Smyrnovska rural community } \\
\text { Tavrijska rural community } \\
\text { Shyrokivska rural community }\end{array}$ \\
\hline
\end{tabular}

Source: grouped by the author

Table 5

Groups of united territorial communities

\begin{tabular}{|l|c|c|}
\hline \multicolumn{2}{|c|}{ Group 1 - with high kinetic energy rate and a considerable number of community members } \\
\hline Berestivska rural community & Kinetic energy rate & Number of community members, persons \\
\hline Bilenkivska rural community & 37141,51 & 19648 \\
\hline Velykobilozerska rural community & 12860,04 & 22273 \\
\hline Veselivska settlement community & 2543,33 & 1636 \\
\hline Komyshuvaska settlement community & 15758,1 & 11309 \\
\hline Osypenkivska rural community & 6575,88 & 17100 \\
\hline Pavlivska rural community & 9358,27 & 14698 \\
\hline Chernigivska settlement community & 2051,11 & 11201 \\
\hline Average value & 6700,43 & 15133 \\
\hline \multicolumn{1}{|c|}{ Group 2- with low kinetic energy rate and an inconsiderable number of community members } \\
\hline Voskresenska rural community & 244,53 & 13157 \\
\hline Ostrykivska rural community & 17,7 & 3846 \\
\hline Prymorska urban community & 112,93 & 5695 \\
\hline Smyrnovska rural community & 215,24 & 4494 \\
\hline Tavrijska rural community & 1359,96 & 5800 \\
\hline Shyrokivska rural community & 639,05 & 9226 \\
\hline Average value & 966,1 & 5223 \\
\hline
\end{tabular}

Source: grouped by the author

$$
A=S^{-1}\left(\bar{X}_{1}-\bar{X}_{2}\right)=\begin{aligned}
& 5,3 \cdot 10^{31} \\
& 2,8 \cdot 10^{29}
\end{aligned}
$$

The discriminant function testifies that the first factor is more significant than the second is, that is, the kinetic energy rate prevails over the number of community members in the group.

The next step is to calculate average values of the discriminant function $\left(\overline{f_{1}}, \overline{f_{2}}\right)$ and meaning of discrimination constant $(c)$ :

$$
\begin{aligned}
& \bar{f}_{1}=11623,6 \cdot 5,3 \cdot 10^{31}-15133 \cdot 2,8 \cdot 10^{29}=6,2 \cdot 10^{35},(6) \\
& \bar{f}_{2}=966,1 \cdot 5,3 \cdot 10^{31}-5223 \cdot 2,8 \cdot 10^{29}=5,2 \cdot 10^{35},(7) \\
& c=\frac{\bar{f}_{1}+\bar{f}_{2}}{2}=\frac{6,2 \cdot 10^{35}+5,2 \cdot 10^{34}}{2}=3,4 \cdot 10^{35},
\end{aligned}
$$

We classify new objects, i.e. united territorial communities, included into the groups with the indirect correlation between the kinetic energy rate indicators and the number of community members. We put values of their characteristics in a discriminant function and compare them with discrimination constant. The results are presented in Table 6.

The Table 6 data indicate that all examined communities attributed to groups with low kinetic energy rate and an inconsiderable number of community members. This confirms the $\mathrm{H} 2$ hypothesis of a direct correlation between the amount of human resources and kinetic energy rate.

It should be noted the existence of the 4\% group of communities with high kinetic energy rate and an 
Table 6

Classification of new objects - united territorial communities

\begin{tabular}{|l|c|c|c|c|}
\hline \multicolumn{1}{|c|}{ Community } & Kinetic energy rate & $\begin{array}{c}\text { Number of community } \\
\text { members, persons }\end{array}$ & $\begin{array}{c}\text { Discriminant } \\
\text { function's value }\end{array}$ & Group \\
\hline Vodyanska rural community & 244,53 & 13157 & $1,65822 \mathrm{E}+34$ & 2 \\
\hline Girsivska rural community & 844,63 & 10794 & $4,76119 \mathrm{E}+34$ & 2 \\
\hline Gulyajpilska urban community & 17,7 & 3846 & $2,00735 \mathrm{E}+33$ & 2 \\
\hline Dolynska rural community & 112,93 & 5695 & $7,55175 \mathrm{E}+33$ & 2 \\
\hline Kamjansko-Dniprovska urban community & 215,24 & 4494 & $1,26193 \mathrm{E}+34$ & 2 \\
\hline Komysh-Zoryanska settlement community & 1359,96 & 5800 & $7,34314 \mathrm{E}+34$ & 2 \\
\hline Malotokmachanska rural community & 639,05 & 9226 & $3,63188 \mathrm{E}+34$ & 2 \\
\hline Orihivska urban community & 1768,61 & 3166 & $9,42759 \mathrm{E}+34$ & 2 \\
\hline Preobrazhenska rural community & 1918,3 & 2930 & $1,02115 \mathrm{E}+35$ & 2 \\
\hline
\end{tabular}

Source: calculated by the author

inconsiderable number of community members. After all, it could be argued, that a significant development rate of these communities, which is determined by the kinetic energy rate, is achieved not by the number of people, but by the accumulation of another kind of energy.

Another kind of energy analysed in the study is a potential energy $\left(W_{p}\right)$, i.e. energy, which is determined by the relationship between people, the origin and strength of interactions between them.

In our research (Pereverzieva, 2018), to quantify the level of human resources interactions within a particular community, it was suggested to use the interactions coefficient $\left(k_{\text {int }}\right)$, which determines the strength and nature of these interactions. The coefficient $k_{\text {int }}$ takes into account community members' interactions rate and acts simultaneously as a multiplier. The strength or quality of these interactions leads to synergistic effect. That is, the total "energy" of community's human resources equals not just the sum of each person's "energy", but may either be increased (strengthened) through collective cooperation, or reduced (weakened), for example, by conflict environment.

There are different methods to determine coefficient $k_{\text {int }}$. We offer the following method. The list of $N$ questions $(k=\overline{1, N})$ is determined. They characterize the quality of community members' interactions concerning different types of activities (work, research, creative work) and communication. The question should be formulated in such a way that the answer could be rated on a scale:
1 - if $k_{\text {int }}$ strengthens common qualities of a community,

$0-k_{\text {int }}$ does not impact common qualities,

- 1 -if $k_{\text {int }}$ impacts weakening of community members' cooperation common qualities.

Let the answer to each $k$ question be assessed by value $d_{k} \in\{-1,0,1\}$. Then the coefficient of interactions' value $k_{\text {int }}$ will be determined by the formula:

$$
k_{\text {int }}=\frac{\sum_{k=1}^{N} d_{k}}{N},
$$

where:

$d_{k}$ - assessment of each question's $\mathrm{k}$ answer.

We consider the example of the coefficient of interactions definition (Table 7).

Thus, having determined the criteria, by which it is possible to estimate the coefficient of interactions, we calculate the coefficient of interactions of an ordinary community and an ideal one.

The analysis of the mentioned above criteria produced the following results (Table 8).

The obtained results allow us to make conclusions about the need to improve certain indicators and to determine the deviation level of evaluated object's parameters (a community) from the ideal value. Thus, we have an opportunity to improve indicators with the lowest value, which in turn spurs united territorial communities' management efficiency growth.

Based on the foregoing, we summarize that united territorial communities' human resources are the

Table 7

Definition of the coefficient of interactions

\begin{tabular}{|c|c|c|c|c|c|c|c|}
\hline Work activity & $d_{k}$ & Research activity & $d_{k}$ & Creative activity & $d_{k}$ & Communication & $d_{k}$ \\
\hline $\begin{array}{l}\text { If a community member cannot be at } \\
\text { work, which form of substitution is the } \\
\text { most widespread: }\end{array}$ & & $\begin{array}{l}\text { - participation in } \\
\text { research projects }\end{array}$ & 1 & \multirow{4}{*}{$\begin{array}{l}\text { Joint creative } \\
\text { projects and } \\
\text { development }\end{array}$} & 1 & Joint activities: & \\
\hline - replacement and taking on duties & 1 & \multirow{3}{*}{$\begin{array}{l}\text { - participation in } \\
\text { conferences }\end{array}$} & \multirow{3}{*}{1} & & & - holidays & 1 \\
\hline - to take on someone's duties partially & 0 & & & & & - concerts & 1 \\
\hline - work is not fulfilled & -1 & & & & & -picnics & 1 \\
\hline
\end{tabular}

Source: Compiled by the author 
Table 8

\section{Calculation of the coefficient of interactions}

\begin{tabular}{|l|c|c|}
\hline \multirow{2}{*}{\multicolumn{1}{|c|}{ Areas of activity }} & \multicolumn{2}{|c|}{ Evaluated object } \\
\cline { 2 - 3 } & $\begin{array}{c}\text { Ordinary } \\
\text { community } \\
\text { (traditional } \\
\text { calculation) }\end{array}$ & $\begin{array}{c}\text { Ideal community } \\
\text { (methodology) }\end{array}$ \\
\hline Work activity & 0 & 1 \\
\hline Research activity & 1 & 2 \\
\hline Creative activity & 1 & 1 \\
\hline Mutual communication & 2 & 3 \\
\hline Coefficient of interactions & 1,4 & 1,7 \\
\hline
\end{tabular}

Source: calculated by the author

combination of human physical and mental abilities, described by personal qualities that lead to interactions between community members, creating a united group with a common objective. It is based not only on the division of roles and positions but on mutual support and assistance in the realization of common goals - the development of a territorial community for the sake of life standards' improvement.

In our opinion, it is relevant to determine the correlation between kinetic and potential energy:

$$
\begin{gathered}
W_{\kappa}=\frac{m V^{2}}{2}, \\
m=\frac{2 W_{k}}{V^{2}}, \\
W_{p}=m g h,
\end{gathered}
$$

where:

$W_{p}$ - potential energy;

$m$ - the number of community members, persons;

$g=1$, it is a constant value (in Physics formula);

$h$ - coefficient, which characterizes interactions between community members.

$$
m=\frac{W_{p}}{g h},
$$

We obtain the following correlation between human resources' kinetic and potential energy:

$$
\frac{W_{p}}{g h}=\frac{2 W_{k}}{V^{2}},
$$

Formula 14 shows a direct correlation between the coefficient of community interactions and its development rate, that is, the higher the level of interactions between human resources is, the faster the community develops. This confirms the hypothesis $\mathrm{H} 3$ concerning the impact of interactions on the community development rate.

\section{Findings}

To confirm the correlation between business entity's development rate and amount of human resources, we used the analytical toolkit and methodical approach to grouping, which made it possible to identify four community groups: with high kinetic energy rate and a considerable number of community members;

with low kinetic energy rate and an inconsiderable number of community members;

with low kinetic energy rate and a considerable number of community members;

with high kinetic energy rate and an inconsiderable number of community members.

Specification and grouping allowed us to prove the fact of correlation between the development rate and the amount of human resources, as well to determine the nature of the dependency. The study results presented in Table 4 and illustrated by the example of 23 communities show the direct correlation between the number of community members and its development rate (56\%): 8 communities (35\% of the total number of studied communities) had high kinetic energy rate and significant number of community members; 6 communities $(21 \%$ of the total number of studied communities) had low kinetic energy rate and a small number of community members.

Study findings show that for $44 \%$ of communities, the development rate slightly depends on the number of members. Another type of energy, which "directs" development, proves the fact: 7 communities (30\% of the total number of studied communities) had low kinetic energy rate and considerable amount of members; 2 communities ( $4 \%$ of the total number of studied communities) had high kinetic energy rate and inconsiderable number of members. This is the energy of human resources ' interactions - potential energy.

The discriminatory analysis was used as another tool for grouping to confirm the results.

The toolkit allowed us to quantify the community as a group-member characterized by the direct correlation between the kinetic energy rate and the amount of human resources. We managed to find out not only the real dependency itself but also its nature.

For convenience, we summarize the results of the hypotheses in the table below:

Table 9

\section{Summary of findings}

\begin{tabular}{|l|l|}
\hline Hypotheses: & \\
\hline $\begin{array}{l}\text { H1: human resources energy impacts business } \\
\text { entity's development }\end{array}$ & Is adopted \\
\hline $\begin{array}{l}\text { H2: there is a direct correlation between business } \\
\text { entity's kinetic energy rate (development rate) and } \\
\text { amount of human resources }\end{array}$ & Is adopted \\
\hline $\begin{array}{l}\text { H3: potential energy (coherence energy) impacts } \\
\text { business entity's development rate }\end{array}$ & Is adopted \\
\hline
\end{tabular}

Source: own study

\section{Conclusions}

In the article, the impact of human resources' "energy" on the development of a business entity was studied. We considered two types of human resources' "energy": 
kinetic energy, which characterizes the development rate and potential energy, which is the energy of interactions between people. The last may affect the functioning of a business entity and determines the prospects for its further development. We considered the activities of united territorial communities as the example of business entities. Although certain legally defined criteria exist, they are formed voluntary, which may be the prerequisite for the significant human resources' "energy" rate at the start-up stage. It was proved by the Table 1 data, which contains data and calculations of human resources and certain kinetic energy rate correlations, and illustrates that in spite of an insignificant period of a community's existence, they have considerable development rate because of their human resources.

To evaluate a potential energy rate, we proposed only a separate approach that can be used to quantify the coherence "energy", which is characterized by qualitative indicators. It is difficult to define them quantitatively. We can only propose a certain approach, which was presented in Tables 7-8.

To define interactions between community's development rate and human resources coherence, the logic transformation of kinetic and potential energy formulas was fulfilled. Logic transformations illustrated a direct correlation between community's coefficient of interactions and its development rate, as the higher rate of human resources' interactions is, the quicker a community develops.

Our work is not without limitations. We propose only one approach, which allows calculating potential energy based on the coefficient of interactions. Considerable time and financial resources are required for this approach's implementation. Therefore, our task for further research is to find an effective approach precisely for quantifying the level of human resources interactions. As our study shows, there is a direct correlation between the kinetic and potential energy of human resources, i.e. certain socio-economic system's (enterprise, community) development rate and interactions of its components. Identification and quantitative assessment also require planning of an effective mechanism aimed at human resources "energy" management to preserve and develop it in future. This causes chain reaction, contributes to the achievement of high efficiency and effectiveness of business entities. Future work will grapple with some of these issues.

\section{References:}

Adaptirovannaya versiya knigi «Bolee chem ekonomicheskiy rost» [Adapted version of the book «More than economic growth»]. Retrieved from: www.worldbanc.org.ru (accessed 5 April 2018).

Becker G. S. (2003) Chelovecheskoe povedenie. Ekonomicheskiy podkhod. Izbrannye trudy po ekonomicheskoy teorii [The economic approach to human behaviour. Selected papers on economic theory]. Moscow: GUVShE (in Russian).

Bolshoy entsiklopedicheskiy slovar [Great Encyclopaedic Dictionary]. Retrieved from: http://dic.academic.ru/ misc/enc3p.nsf/ListW (accessed 5 April 2018) (in Russian).

Chelovecheskie resursy v amerikanskom menedzhmente [Human resources in American management]. Retrieved from: http://www.secreti.info/p58m.html (accessed 5 April 2018).

Dokashenko L.V., Bobrova, V.V. (2015) Rol chelovecheskikh resursov v innovatsionnoy ekonomike [The role of human resources in innovation economy]. Vestnik OGU, vol. 13, no 132, pp. 141-146 (in Ukrainian).

Fitz-enz J. (2006) Rentabelnost investitsiy v personal: izmerenie ekonomicheskoy tsennosti personala: [rol chelovecheskogo kapitala $v$ razvitii predpriyatiya, vychislenie koeffitsienta okupaemosti investitsiy, demografiya rabochey sily, upravlenie raskhodami, tendentsii, prognozy i predskazaniya] [The ROI of Human Capital: Measuring the Economic Value of Employee Performance: [human capital's role in enterprise's development, return on investment measurement, labour force demography, cost management, trends, forecasts and predictions]. Moscow: Vershina (in Russian).

Flamholtz E.G. (1999) Human Resource Accounting: Advances in Concepts, Methods and Applications. New York: Springer.

Hillery J.A. (1955) Definitions of community: areas of agreement. Rural Sociology, no 20, pp. 111-123.

Investytsiinyi potentsial obiednanykh terytorialnykh hromad Zaporizkoi oblasti [Investment potential of Zaporizhzhya region united territorial communities]. Retrieved from: http://investment.zoda.gov.ua/Communities (accessed 5 April 2018).

Jonassen C.T. (1959) Community Typology - Community Structure and Analysis, N.-Y.: [s. n.].

Hayek F.A. (2006) Pravo, zakonodatelstvo i svoboda: sovremennoe ponimanie liberalnykh printsipov spravedlivosti $i$ politiki [Law, Legislation and Liberty: A new statement of the liberal principles of justice and political economy]. Moscow: IRISEN [in Russian].

Hughes-Jr., James E. (2007) Bogatstvo semi. Kak sokhranit chelovecheskiy, intellektualnyy i finansovyy [Family Wealth: Keeping It in the Family]. Moscow: «Olimp-BIZNES» (in Russian).

Ministerstvo rehionalnoho rozvytku budivnytstva ta zhytlovo-komunalnoho hospodarstva Ukrainy. Hromady [Ministry of regional development, construction, housing and communal services of Ukraine. Communities]. Retrieved from: http://decentralization.gov.ua/gromada/416 (accessed 5 April 2018). 
Pereverzieva A.V. (2018) Synerhetychnyi efekt u rozvytku liudskykh resursiv obiednanykh terytorialnykh hromad [Synergetic effect of the united territorial communities' human resources`development]. Derzhava ta ekonomika, no 3, pp. $71-74$ (in Ukrainian).

Schulz T.W. (1960) Capital formation by education. Journal of Political economy, no 6, pp. 571-583.

Semiv L.K. (2004) Rehionalna polityka rozvytku liudskykh resursiv v umovakh transformatsii ekonomiky Ukrainy [Regional policy of human resources development amid transformation of the economy of Ukraine]. Lviv: In-t rehionalnykh doslidzhen NAN Ukrainy (in Ukrainian).

Shchokin H.V. (2006) Upravlinnia liudskymy resursamy: poniatiino-terminolohichnyi slovnyk [Human resources management: conceptual and terminology dictionary], Kyiv: MAUP (in Ukrainian). 